\title{
Hibridni odgovor EU-a na rusku politizaciju plinske trgovine u cilju jačanja energetske sigurnosti
}

\author{
JELENA RADIĆ ĐOZIĆ \\ Ministarstvo unutarnjih poslova Repubilke Hrvatske
}

\begin{abstract}
Sažetak
Europska unija se politizaciji svoje plinske trgovine s Ruskom Federacijom u 21. stoljeću prilagođava hibridnim modelom, koji je mješavina različitih mjera. Kako bi spriječila ili barem ublažila rusko korištenje te trgovine u realističkoj politici moći, odgovara mjerama koje se sve više udaljuju od ekonomske, osobito slobodnotržišne, i približavaju političkoj perspektivi, jer je unošenje političkog elementa u vanjskotrgovinski odnos tražilo netržišne odgovore. $\mathrm{Na}$ temelju analize odgovora Europske unije na prijetnju čije je ishodište u ruskoj politizaciji plinske trgovine moguće je pratiti postupnu transformaciju liberalno-ekonomskog identiteta Europske unije u sve više geopolitički u svijetu koji postaje sve realističniji kako u energetskim pitanjima konkretno tako i u međunarodnim poslovima općenito. Europska unija je u svoju energetsku politiku uvrstila koncepte solidarnosti i suvereniteta, a visoki predstavnik za zajedničku vanjsku i sigurnosnu politiku Europske unije traži od nje da "ponovno nauči jezik moći”.
\end{abstract}

Ključne riječi: Ruska Federacija, Europska unija, plinska trgovina, politizacija, geopolitički identitet, solidarnost, suverenitet

\section{Uvod}

Država se vratila, kako u pogledu sigurnosti opskrbe i proizvodnje energenata tako i u pogledu imperativa smanjenja emisija $\mathrm{CO}_{2}$. Energenti su se vratili kao instrument vanjske politike i državnog umijeća. Jasno se osporava ideja tržišta kao birokratskog upravljačkog mehanizma i cijela liberalna paradigma u međunarodnoj trgovini (Prontera, 2017, str. 6).

Nova uloga plinske trgovine u odnosima između Europske unije (EU) i Ruske Federacije (RF), inicirana ruskom politizacijom plinske trgovine, koju RF, doduše, negira iako je u Energetskoj strategiji $R F$-a do 2020. iz 2003. eksplicitno navedeno 
da energetski sektor vidi kao "instrument za vođenje unutarnje i vanjske politike" (Vlada RF-a, 2003), rezultirala je prilagodbom EU-a na transformaciju uloge tog izvorno ekonomskog odnosa. EU je u energetskim odnosima počeo donositi odluke koje ne počivaju isključivo na ekonomskoj učinkovitosti, pa je istraživanje odgovora EU-a na transformaciju uloge plinske trgovine u odnosima s RF-om ukazalo i na promjenu identiteta EU-a, onoga što EU jest. U ekonomskim aktivnostima EU je prestao biti isključivo liberalno-ekonomski akter koji državi odriče bilo kakvu ulogu u ekonomiji i na trgovinu gleda isključivo iz slobodnotržišne perspektive, iz ugla ekonomske dobiti. To što je EU ekonomske aktivnosti počeo podvrgavati ne samo regulaciji nego i strateškim procjenama, upotpunjuje nastojanja EU-a da jačanjem svog vanjskopolitičkog i sigurnosnog identiteta, koji ostvaruje kako donošenjem zajedničkih vanjskopolitičkih odluka tako i realizacijom vojnih i civilnih operacija upravljanja krizama na različitim kontinentima, postane pravi geopolitički akter. Primjena nove, realističko-političke paradigme na ekonomskom području ukazuje na pojačanu želju EU-a da ne bude "uljez" (Szulecki i Westphal, 2018, str. 182) u sve realističnijem svijetu ne samo ekonomskih poslova nego i poslova u međunarodnim odnosima općenito.

Nova predsjednica Europske komisije (EK) Ursula von der Leyen je, objašnjavajući svoje prioritete na predstavljanju nove organizacije i novih članova EK u rujnu 2019., ciljano izabrala geopolitički diskurs i otvoreno najavila da će njezin EK biti “geopolitička Komisija" (EC-PR, 2019a), što je važno ne samo stoga što ukazuje na promjenu identiteta EU-a nego i stoga što diskursi često imaju moć mijenjati realnost. Na geopolitičko postavljanje upućuje i moto njemačkog predsjedanja Europskim vijećem (EV) u drugoj polovici 2020.: "Učiniti Europu ponovno snažnom" kako joj ne bi "propisivali", kako bi mogla "ići vlastitim putem i geopolitički uobličavati” (Maas, 2020), i to na temelju primjene principa suvereniteta i solidarnosti. Kako je pojasnio njemački ministar vanjskih poslova Heiko Maas (2020a) u svom govoru u Bundestagu povodom njemačkog preuzimanja predsjedanja EU-om, solidarnost daje "sposobnost potvrđivanja europskih vrijednosti i interesa u sve jačoj konkurenciji velikih sila". Takav smjer EU-a najavio je već prethodnik na čelu EK Jean-Claude Juncker u govoru o stanju Unije 2018. naglasivši da će "Europa uzeti svoju sudbinu u svoje ruke" i da dolazi razdoblje "europskog suvereniteta", koji će počivati na spajanju suvereniteta država članica i više solidarnosti (Juncker, 2018).

Istraživanje odgovora EU-a na novu ulogu plinske trgovine s RF-om u ovom radu daje dobru podlogu za praćenje postupnog mijenjanja ekonomskog dijela identiteta EU-a. Plinska trgovina između EU-a i RF-a uspostavljena je u doba Hladnog rata kao isključivo ekonomski odnos temeljen na liberalnoj paradigmi međuovisnosti i suradnje, neometan (potican) od politike. Nakon Hladnog rata RF ju je politizirao pretvorivši je u instrument političke moći i pitanje visoke politike, a EU ju je 
počeo razumijevati kao prijetnju svom vanjskom suverenitetu, "slobodi od obveze primanja naredbi i kontrole od stranih drugih, vladanju bez ometanja izvana" (Morgan, 2010, str. 31-32) ${ }^{1}$ te ju je, nakon neuspjelog pokušaja dovođenja u područje sigurnosti, također politizirao.

U nastavku će se, nakon što se definira okvir i način istraživanja te pojasne ključni koncepti, pokazati kako je EU, u nastojanju da ojača svoju energetsku sigurnost, odgovarao na izazove i prijetnje uzrokovane instrumentalizacijom plinske trgovine te kako taj hibridni odgovor na rusku politizaciju plinske trgovine ukazuje na transformaciju identiteta EU-a.

\section{Teorijski, metodološki i konceptualni okvir}

Plinska trgovina temeljno je ekonomski odnos, koji se može istraživati iz različitih perspektiva, a u ovom se radu istražuje iz politološke: korištenje ekonomskog odnosa kao instrumenta vanjskopolitičke moći upućuje na međunarodnu političku ekonomiju, ali i na sigurnosne studije, jer "kada se koristi moć ili prijeti njezinim korištenjem da bi jedan akter dobio nešto od drugog, sigurnost postaje središnje obilježje političke rasprave" (Kolodziej, 2005, str. 22); kako je jedan od aktera EU, u istraživanju su korišteni i uvidi europskih studija. Veza između ekonomije (trgovine) i politike uobičajeno se istražuje iz liberalne ili realističke paradigme i naglasak je na pitanju doprinosi li miru ili sukobu; u ovom se radu istražuje veza trgovinskog odnosa i moći odnosno prijetnje u materijalnom, ali i perceptivnom smislu, što upućuje na konstruktivističku perspektivu. Ta perspektiva u ovom radu nije zamjena, nego dodatak realističkoj perspektivi koji će pomoći razumjeti objektivno i subjektivno konstruirane i percipirane moć i prijetnju, kao i diskurzivno stvaranje sigurnosti u procesu sekuritizacije.

Provedeno je kvalitativno istraživanje, pri čemu je osnovna tehnika prikupljanja podataka bilo čitanje: u pisanim su dokumentima traženi podaci o materijalnim čimbenicima i diskursima vezanima uz predmet istraživanja. Prednost pri izboru izvora podataka dana je institucionalnim dokumentima i izjavama dužnosnika zbog njihova legitimiteta i moći da uokviruju pitanja na određen način. To je omogućilo spoznaju da se kroz vrijeme mijenjao način sagledavanja izazova i prijetnji vezanih uz plinsku trgovinu s RF-om u EU-u. Radovi drugih znanstvenika korišteni su kao “jedan od podataka" (Jeđud, 2007, str. 93), kada su sadržavali činjenice ili prikazivali teorije vezane uz predmet istraživanja, ili su konzultirani u vezi s metodologijom prikupljanja i analiziranja podataka te epistemiologijom. U empirijskom su

${ }^{1}$ Suvremeni sigurnosni studiji proširuju opseg prijetnji izvan fizičke upotrebe vojne sile, a značenje egzistencijalne prijetnje državi kao referentnom objektu izvan fizičke sigurnosti i teritorijalnog integriteta, pa se prijetiti može i konstitutivnom principu poput (vanjskopolitičkog) suvereniteta. 
istraživanju korištene metode kvalitativne tematske analize i kritičke analize diskursa. Obje su metode vođene podacima i predstavljaju hibridni model između induktivnog i deduktivnog, abduktivan način zaključivanja koji počiva na "stalnom feedbacku između analize i prikupljanja podataka” (Meyer, 2015, str. 16), a razlikuju se po tome što je prva metoda više studija znanja, a druga studija značenja.

Riječ "hibrid" u naslovu rada nije izabrana kako bi ukazala na metode korištene u istraživanju, nego stoga što najbolje opisuje različite fenomene vezane uz plinsku trgovinu između EU-a i RF-a te daje mogućnost definiranja odgovora EU-a na rusku politizaciju plinske trgovine. U prirodnim znanostima riječ "hibrid" izvorno je označavala spajanje nespojivog, u smislu križanja jedinki koje pripadaju različitim vrstama (Hrvatski jezični portal, n. d.); to je često imalo negativnu konotaciju, pa se rezultat nazivao mješancem, bastardom. Primjeni koncepta u ovom radu bliže je objašnjenje da je hibridno ono "što ima ili je nastalo kombinacijom dva ili više elemenata obilježenih različitošću u porijeklu, sastavu ili pojavnosti” (MerriamWebster, n. d.), koje je lišeno kvalifikacije, iako spajanje elemenata može donijeti nova, poželjna svojstva (kao u slučaju kombiniranja korisnih osobina dvije biljke u genskoj manipulaciji).

Hibridnost je jedno od obilježja energetskih politika općenito, koje su oduvijek "kombinacija tržišnih snaga i političke odnosno geopolitičke dinamike" (Prontera, 2017, str. 17). Povezano je i s načinom odlučivanja o energetskoj politici u EU-u: riječ je o "hibridnom tipu kreiranja politike" (Wallace i Reh, 2015, str. 72), koji nadilazi dihotomiju između intergovernmentalizma, kada odlučivanje pretpostavlja usuglašavanje različitih interesa i ideja država članica, i supranacionalizma, kada u odlučivanju dominira EK na temelju većinskog odlučivanja država članica, jer je to područje podijeljene odgovornosti između institucija EU-a i država članica. Riječ "hibrid" opisuje i mikrostrukturu EU-a, koji nije ni država ni međunarodna organizacija, nego "jedinstveni oblik političke organizacije... (koji) miješa kontinuitet suvereniteta s novim oblicima" (Buzan i Wæver, 2003, str. 352). Prisutna je i u sintagmi hibridno ratovanje, koja se koristi kao naziv za način na koji RF nastoji povratiti svoju moć i utjecaj u svijetu, a koji također označava mješavinu: strategiju jedinstvenog, simultanog korištenja konvencionalnih vojnih sposobnosti i taktika te nekonvencionalnih, neregularnih (obavještajnih, pobunjeničkih, ponekad i terorističkih) taktika i aktivnosti u koje, između ostalog, spada i korištenje plinske trgovine u politici moći.

I koncept energetske sigurnosti, za koji je interes političke, publicističke i znanstvene javnosti obnovljen upravo zbog nove uloge plinske trgovine u odnosima između EU-a i RF-a od sredine 2000-ih, u aktualnom je kontekstu hibrid. Koncept energetske sigurnosti označuje netradicionalno sigurnosno pitanje (tradicionalno su sigurnosnim pitanjima smatrana vojna i vanjskopolitička pitanja), a njegovi 
su elementi mješavina netradicionalne prijetnje (nevojne), tradicionalnog objekta kojem se prijeti (država ili EU kao protodržava, nadnacionalna integracija koja ima ambiciju smatrati se državom) i tradicionalne vrste instrumenta (postoje povijesni primjeri korištenja ekonomskog instrumenta, vanjske trgovine općenito i trgovine energentima, u vojne svrhe, a nova je i u tom smislu netradicionalna samo vrsta energenta - plin kojega RF ima u izobilju, a EU ovisi o njegovu uvozu), koji se koristi na tradicionalan način (kao instrument realističke tvrde moći). Taj se instrument nastoji ojačati na tradicionalan način u materijalnom smislu (obustavom opskrbe, manipulacijom cijenom, monopolom) i na netradicionalan način - diskurzivnim korištenjem tradicionalne gramatike sigurnosti uz plinsku trgovinu kao tradicionalno nesigurnosno područje, pri čemu se predlažu i odgovori koji imaju obilježje tradicionalnih sigurnosnih praksi, primjerice u pokušajima sekuritizacije. Za razliku od konvencionalnih definicija energetske sigurnosti koje su većinom tržišno orijentirane i ograničene na sigurnost opskrbe i stabilnost cijene, u ovom se radu koncept energetske sigurnosti definira u aktualnom kontekstu iz tradicionalne, realističke logike sigurnosti. U fokusu nije samo sigurnost opskrbe, nego je prioritet dan ublažavanju političko-sigurnosnih eksternalija plinske trgovine (poput prijetnji temeljnim nacionalnim vrijednostima), pa se energetska sigurnost u ovom radu definira kao odsustvo prijetnje vanjskopolitičkoj sigurnosti putem korištenja asimetrične međuovisnosti u plinskoj trgovini kao instrumenta moći. ${ }^{2}$

Odgovor EU-a na rusku politizaciju plinske trgovine, što je predmet ovoga rada, svojevrsni je hibridni model, mješavina kratkoročnih i dugoročnih, ekonomskih i neekonomskih, tržišnih i netržišnih mjera, mjera usmjerenih na stranu potražnje, prema unutra, i mjera usmjerenih na stranu ponude, prema van; mjera meke i mjera tvrde moći. Tim hibridnim odgovorom EU nastoji spriječiti, izbjeći ili barem ublažiti rusko korištenje plinske trgovine u politici moći, prilagoditi se uz zadržavanje ekonomske koristi i što više političke autonomije. EU gotovo simultano odgovara tržišnim i netržišnim ekonomskim mjerama, koje su se postupno sve više udaljavale od ekonomske i približavale političkoj perspektivi, za što je osnovni razlikovni kriterij ekonomska učinkovitost. Nova energetska politika EU-a (EP EU) ustvari je "mješavina stare i nove dinamike, politiziranog i tržišnog pristupa" (Prontera, 2017, str. 2), što EU-u daje "hibridni identitet" (Johnson, 2016, str. 53). Za to što su odgovori EU-a na rusku politizaciju plinske trgovine tek postupno postajali "odgovori istom mjerom" zaslužan je (ili bolje reći kriv) u prvom redu izvorni identitet EU-a.

${ }^{2} \mathrm{Na}$ takvu je definiciju energetske sigurnosti primjenjiv O'Sullivanov prijedlog (2013, str. 31) da se umjesto sintagme energetska sigurnost koristi sintagma geopolitika energije. 


\section{Identitet EU-a}

EU je dio liberalne tradicije međunarodnih odnosa, koja uključuje federalizam, funkcionalizam i neofunkcionalizam; od nastanka je "liberalni projekt" (Wunderlich, 2008, str. 31) koji počiva na ograničavanju nacionalnih suvereniteta u pokušaju obuzdavanja nacionalizma i na liberalnim vrijednostima poput demokracije, poštivanja ljudskih prava, transnacionalne suradnje, slobodne trgovine i slobodnog tržišta, i na temelju tih vrijednosti države članice definiraju svoje identitete, nacionalne interese i vanjske politike. EU ni po svojoj strukturi, tj. političko-ekonomskoj organizaciji ne pripada realističkom svijetu nacionalnih država - EU je država sui generis,${ }^{3}$ heterogena postmoderna integracija samo slična državi. Njezine institucionalne karakteristike preslikane su i na političko-sigurnosnu, stratešku kulturu - EU odbacuje politiku moći i zagovara međusobnu suradnju kao put do sigurnosti.

U središtu ekonomske politike EU-a je kompetitivno, liberalizirano i privatizirano tržište, a primarni akteri su privatna poduzeća. EU polazi od toga da su tržišni mehanizmi najbolji u alokaciji svake, pa i energetske robe te najučinkovitiji u korekciji šokova i anomalija (poremećaja ponude i potražnje) na tržištu. Tako slobodno tržište pozitivno utječe na učinkovitost, štiti od visokih cijena i zloporaba te doprinosi transparentnosti, a prostor države maksimalno je sužen, ograničen na područje reda i zakona, eventualno fizičku zaštitu infrastrukture. Vanjsku trgovinu EU doživljava isključivo iz liberalno-ekonomske perspektive, kao odnos u kojem je važna apsolutna dobit (ekonomska i politička dobit oba aktera), i zanemaruje da liberalne pretpostavke vrijede samo u uvjetima savršene tržišne konkurencije, što je u praksi rijetkost, kao i da vanjska trgovina može biti izvor moći (Hirschman, 1980, str. 68).

U plinskoj trgovini sudjeluju dva aktera koji pripadaju različitim političkoekonomskim svjetovima: dok je jedan postmoderna nadnacionalna integracija utemeljena na liberalnoj demokraciji i slobodnotržišnoj ekonomiji, drugi je nacionalna država s autoritarnim režimom i državnim kapitalizmom kao ekonomskim mode$\operatorname{lom}^{4} \mathrm{u}$ realističkoj tradiciji, u kojoj su relativni dobici važniji od apsolutnih. Liberalno-ekonomska perspektiva EU-a suprotstavljena je ruskoj realističkoj, etatističkoj, neomerkantilističkoj, iz koje je politika na prvom mjestu, a ekonomija je tek dio širih prioriteta jake države ili nacionalne sigurnosti. U središtu ekonomskog modela je država, primarni akter je vlada, a vanjska trgovina je državno pitanje,

${ }^{3}$ EU nije samo puka međunarodna organizacija ili međudržavni forum; ima karakteristike koje ga čine entitetom po sebi; progresivni je eksperiment koji u sebi ima i antiratnu, liberalnu, prosvjetiteljsku, kao i ekonomsku i socijalnu dimenziju (Jović, 2018, str. 384-385, 389).

${ }^{4}$ Državni kapitalizam označava djelomično slobodno tržište, djelomičan državni monopol i djelomičan državni intervencionizam, predstavlja obnovu merkantilističke filozofije. 
jedan od instrumenata na raspolaganju državi za realizaciju sigurnosti ili moći, u prvom redu instrument $u$ geopolitičkoj igri moći, instrument maksimiziranja moći. Važna je relativna ekonomska i politička dobit, povećanje bogatstva i jačanje relativne moći radi zaštite i realizacije različitih ciljeva. Prioritetan cilj vanjske trgovine nije ekonomski, nego politički, pa je vanjska trgovina samo "privremeni aranžman" koji "se lako krši kada se nacionalni interesi osiguravaju drugim strategijama" (Barbieri, 2002, str. 19). ${ }^{5}$

U skladu s realističkom paradigmom RF je nakon dolaska Putina na vlast 2000. godine počeo primjenjivati strategiju ciljane i vješte konverzije plinske trgovine, koja je do tada počivala na apsolutnoj ekonomskoj i političkoj dobiti, u instrument za utjecanje radi postizanja relativnih strateških i taktičkih vanjskopolitičkih ciljeva. Ključni je preduvjet bio unošenje neravnoteže u međuovisnost ${ }^{6} u$ plinskoj trgovini kako bi je RF iskoristio kao instrument političke moći zbog posljedične osjetljivosti odnosno ranjivosti EU-a $\mathrm{a}^{7}$ u plinskoj trgovini. EU je dugo inzistirao na liberalnoj dogmi o simetričnoj međuovisnosti, na tome da RF treba čvrstu valutu u istoj mjeri u kojoj EU treba plin, no RF je odlučio međuovisnost iskoristiti za postizanje relativne političke dobiti. Stoga je jačao asimetriju međuovisnosti na štetu EU-a: materijalno - manipulacijom opskrbom i cijenom te monopolističkim strukturiranjem tržišta, ${ }^{8}$ i perceptivno - jačajući svoj samokonstruirani identitet energet-

5 To su dva idealnotipska modela upravljanja ekonomskim poslovima - tržišni odnosno državni, dok je u energetskim poslovima zbog strateške važnosti energenata tradicionalno prisutan model savezničke države (Prontera, 2017, str. 24) u kojem država radi za privatna energetska poduzeća i podupire njihove aktivnosti u inozemstvu. U vrijeme uspostave plinske trgovine država je u državama članicama ekonomskih zajednica imala određenu ulogu, nikada istu u svima, primjerice davala je državne garancije za izvozne kredite u paketu s plinskim sporazumima. Tada su se podupirali nacionalni “energetski šampioni” (velika, strateška, vertikalno integrirana energetska poduzeća), koji posjeduju značajne financijske kapacitete i na temelju njih pregovaračku moć, a čuvari su i nacionalnih tržišta. Međutim, od sredine 1980-ih u EU-u se inzistira na dokidanju tog modela u korist liberalizacije i integracije energetskih tržišta.

${ }^{6}$ U pionirskoj studiji o vezi ekonomije i politike u međunarodnim odnosima iz 1945. Albert Hirschman (1980) ustvrdio je da asimetrija ovisnosti u vanjskoj trgovini vodi jačanju moći utjecanja, ovisnosti, utjecaju, dominaciji; vanjska trgovina u tom slučaju više ne služi nadoknađivanju limitiranih resursa, nego se koristi kao instrument moći i krije bitan "đavolji potencijal" za impregniranje ekonomskih i političkih odnosa. Stoddard (2012, str. 347, prema Kester, 2018) asimetriju međuovisnosti u vanjskotrgovinskom odnosu naziva "kratkoročnom disruptivnom moći”, Emerson (1962, str. 33-34) ističe da međuovisnost ne neutralizira moć u odnosu, a za Waltza (2000, str. 10) je "međuovisnost eufemizam koji prikriva ovisnost".

${ }^{7}$ Osjetljivost i ranjivost su sekundarne mjere za važnost trgovine za aktere.

8 Prema državama bližeg inozemstva RF je prije dolaska Putina na vlast koristio prekid ili prijetnju prekidom opskrbe i manipulaciju cijenom; istu metodu koristi i protiv EU-a, no u prvom planu je strukturiranje trgovine i tržišta na monopolistički način. 
ske supersile, ${ }^{9}$ što pojačava percepciju prijetnje, pri čemu nije važno je li prijetnja realna, jer svakako utječe na ishod i pretvara plinsku trgovinu iz kooperativnog $\mathrm{u}$ kompetitivan, ako ne i konfliktan odnos, izaziva strah i omogućuje RF-u natproporcionalan utjecaj.

Umanjivanje opasnosti od ovisnosti tipično za liberalno-ekonomsku paradigmu problematično je tim više što se i ovisnost (kao sinonim asimetrične međuovisnosti) može prelijevati, pa vanjskotrgovinska ovisnost može voditi drugim oblicima ekonomske i neekonomske ovisnosti (Barbieri, 2002, str. 12), dok se iz neofunkcionalističke perspektive temeljene na liberalnoj paradigmi prelijeva samo suradnja. Liberalno-demokratski i tržišno-ekonomski identitet EU-a utjecao je na način razumijevanja plinske trgovine i odredio način prilagodbe, odgovor na politizaciju. Politizacija u slučaju plinske trgovine između EU-a i RF-a pretpostavlja ciljano korištenje te trgovine za realističko maksimiziranje moći, pa je prilagodbu otežavalo proturječje između ostvarivanja ekonomskog cilja povećanja blagostanja u liberalnoj tradiciji i političkog cilja jačanja moći u realističkoj tradiciji. Iako ostvarenje ta dva cilja ne mora uvijek biti u proturječju, ${ }^{10} \mathrm{u}$ konkretnom je slučaju prvotno dovelo do drukčije interpretacije plinskog odnosa: EU ga je interpretirao isključivo u ekonomskim terminima, "u terminima trgovine, a RF u terminima geopolitike" (Goldthau i Sitter, 2014, str. 3).

\section{Ekonomski odgovori EU-a}

U 21. stoljeću plinsku trgovinu naslijeđenu iz hladnoratovskog doba RF je počeo koristiti u politici moći, a EU percipirati kao nametljivu, agresivnu, kao vanjsku sigurnosnu prijetnju. EU nije mogao eliminirati tu trgovinu, nije mogao postati plinski neovisan, ili supstituirati, u potpunosti zamijeniti izvor plina, pa je nastojao postati energetski sigurniji, različitim mjerama smanjiti trošak korištenja plinske trgovine u politici moći, prilagoditi se uz zadržavanje ekonomske koristi i što više političke autonomije. Isprva je EU u kompenzacijskoj prilagodbi na novu ulogu koju je RF dodijelio plinskoj trgovini bio ograničen svojim poimanjem svijeta iz

9 Klare (2008, str. 88, prema Johnson, 2016, str. 113) definira energetsku supersilu kao silu koja je sposobna upravljati svojim izvanrednim bogatstvom resursima kao ogromnim, geopolitičkim utjecajem. Identitet RF-a kao energetske supersile razradio je Putinov glavni ekonomski savjetnik od 2005. I. Šuvalov.

${ }^{10}$ Maksimizacija dobiti (blagostanja) i maksimizacija moći mogu biti komplementarni ciljevi, primjerice merkantilisti su zagovarali kratkoročno reduciranje nacionalne autonomije radi stjecanja bogatstva kako bi dugoročno ojačali moć i realizirali sigurnosne ciljeve, jednako kao što je RF podržavio i iskoristio energetsku (u prvom redu naftnu) trgovinu za jačanje ekonomske moći, što je omogućilo unutarnjopolitičku konsolidaciju i veću vanjskopolitičku autonomiju, a na kraju i veću vanjskopolitičku moć. 
liberalno-ekonomske paradigme i uvjerenošću u korisnost ideja o slobodnom tržištu, te je prva reakcija bila ekonomsko-tržišna. EU je kao prava "normativna sila"11 isprva inzistirao na normama koje su jačale internu integraciju i uvodile regulaciju plinskog tržišta, a zatim na eksternalizaciji tih tržišnih i regulatornih normi na sve aktere u plinskoj trgovini, na konceptu vanjskog energetskog upravljanja. Cilj je bio natjerati drugog aktera u plinskoj trgovini na harmonizaciju plinske politike s plinskom politikom EU-a, dokinuti monopol i potaknuti tržišno natjecanje između opskrbljivača, u liberalnom uvjerenju da su kompetitivno tržište i neovisna regulacija najbolji način osiguranja opskrbe energentima i predvidljivih, niskih cijena. EU je sigurnu opskrbu izjednačio sa slobodnim tržištem, a energetski acquis pokušao je najprije koristiti kao meku moć privlačenja, nametnuti ga preko autoriteta znanja i superiornih vrijednosti poput vladavine prava i ravnopravnog tržišnog natjecanja, no RF, koji je imao drugačiju ideju o tome što je i čemu služi plinska trgovina, nije želio odustati od suvereniteta u plinskoj trgovini zbog ideja "drugih".

Ta vrsta odgovora EU-a na rusku politizaciju plinske trgovine je na unutarnjem planu bila uspješna - od 2014. godine postoji integrirano interno plinsko tržište EU-a, ${ }^{12}$ došlo je do komunitizacije unutarnje dimenzije energetskih politika država članica EU-a i energetska politika je postala novo područje zajedničkog djelovanja EU-a. Na vanjskom planu nije bila uspješna, što najbolje pokazuje primjer Ugovora o energetskoj povelji. Bio je to pravnoobvezujući, multilateralni ugovor koji je poticao energetsku suradnju između EU-a i bivših država članica SSSR-a, u prvom redu RF-a, inzistirao na harmonizaciji zakona o investicijama i liberalizaciji pristupa infrastrukturi i sadržavao pravila o rješavanju sporova. Ugovor u Lisabonu 1994. godine potpisala je 41 država, a stupio je na snagu 1998., te je trebao institucionalizirati dijalog između proizvođača, tranzitnih država i potrošača, no RF ga nije nikada ratificirao (nije pristao na odredbe Tranzitnog protokola o nediskriminacijskom pristupu tranzitnoj energetskoj infrastrukturi, o pravu pristupa treće strane, što bi ugrozilo njegov monopolistički položaj na plinskom tržištu EU-a) i 2009. ga je konačno odbacio. Pokazalo se da je EU civilna sila koja ima premalo normativne moći u odnosu na RF da bi ga mogla obvezati na sigurnu opskrbu plinom, pa je kasnije energetski acquis pokušao nametnuti i putem sudskih presuda, koristeći ga kao tvrdu moć. U tome je bio dijelom uspješan, no to nije predmet interesa ovoga rada.

Pitanje je zašto slobodno tržište nije bilo prikladan i učinkovit odgovor na prekid opskrbe, koji je doveo do poremećaja tržišta. Tržišna reakcija pretpostavljala je kratkoročno preusmjeravanje uvoza i prevođenje oskudnosti u višu cijenu, a dugo-

11 U europskim studijima postoji korpus znanstvene literature koja istražuje koncept normativne sile Europe (NPE), osobito u analizi vanjske politike i vanjskih odnosa.

12 Odluku je donio EV 2011. na temelju Lisabonskog ugovora iz 2009., koji je u čl. 194. propisao uspostavu unutarnjeg energetskog tržišta. 
ročno realokaciju opskrbe i investiciju u nove proizvodne i transportne kapacitete. Nijedno od toga u slučaju plinske trgovine nije ostvarivo: prvi razlog su skupi, fiksni plinovodi koji materijalno i trajno vežu izvoznika i uvoznika, drugi razlog su dugoročni međuvladini ugovori s fiksnom cijenom plina, a treći razlog je to što nema drugog izvoznika koji bi mogao zadovoljiti plinsku potražnju EU-a. Iz navedenih je razloga plinska trgovina (za razliku od naftne) nefleksibilna, a koordinativni učinak cjenovnog mehanizma nije moguć. Problem je bio u tome što bi tržišni odgovori bili prikladni u slučaju da je pitanje plinske trgovine postalo problematično zbog nefunkcioniranja tržišta, ${ }^{13}$ a ne zbog ciljanog ruskog korištenja asimetrije međuovisnosti u plinskom odnosu u politici moći, što je bio ključan razlog nepristanka RF-a na Ugovor o energetskoj povelji. Tako EU nije mogao učinkovito odgovoriti na državotvorne ideje temeljene na moći širenjem slobodnotržišnih i intergracionističkih ideja.

EU je nakon plinskih kriza 2006. i 2009., koje su pojedine države članice ostavile bez opskrbe plinom, postao svjestan da tržište ne može samostalno osigurati sigurnu opskrbu i da unošenje političkog elementa u plinsku trgovinu traži netržišne odgovore. Kada tržište nije isporučivalo dovoljne količine plina po prihvatljivoj cijeni, EU se okrenuo izvantržišnim intervencijama, koje su bile tim potrebnije što u plinskoj trgovini s RF-om ne vrijede uobičajena pravila tržišne utakmice: europska poduzeća koja funkcioniraju na tržišnim principima posluju s ruskim poduzećem oslobođenim pritiska kompetitivnosti, jer Gazprom ima monopol na proizvodnju i distribuciju u zemlji te na izvoz, kontrolira ga država pa trgovina s Gazpromom nije politički neutralna transakcija, a k tome Gazpromu nitko ne može preuzeti tržište EU-a jer ili nema dovoljno plina ili nema transportnih mogućnosti. EU se počeo prilagođavati realističkoj politici moći, svijetu u kojem moć, a ne tržište upravlja zbivanjima, birajući tržišno neučinkovite odgovore i u konačnici politizirajući izvorno isključivo ekonomski vanjskotrgovinski odnos s RF-om. Takav je odabir nespojiv s izvornim liberalno-ekonomskim identitetom EU-a, pa je pretpostavka bila promjena perspektive, drukčije uokvirivanje plinske trgovine, ne više ekonomskim nego političkim okvirom, jer izbor okvira bitno utječe na ishod, na odabir rješenja.

Kako se ne bi u potpunosti odrekao svog liberalno-ekonomskog identiteta, EU se najprije okrenuo rizikofikacijskim rješenjima ${ }^{14}$, nastojeći kratkoročno umanjiti

13 Prema Ciuti (2010), politike dizajnirane da poboljšaju funkcioniranje tržišta su rješenje kada je problem u nesavršenosti tržišta.

${ }^{14}$ Koncept rizikofikacije pretpostavlja razlikovanje rizika od prijetnji s obzirom na različite performativne logike sigurnosti - rizikofikacija je alternativa realističkoj logici sigurnosti, koju slijedi koncept sekuritizacije. Mjere prevencije i upravljanja plinskim krizama čine samostalan sustav čvrstih pravila koja se inkrementalno uspostavljaju u uobičajenoj, redovitoj ili posebnoj zakonodavnoj proceduri; usmjerene su na rizike, a pokušaji sekuritizacije na prijetnje. Termin 
rizik od prekida opskrbe plinom i povećati upravljivost krizama uz što dulje očuvanje aktivnosti tržišta. Direktiva o mjerama zaštite sigurnosti opskrbe plinom (Vijeće EU-a, 2004) dala je prvi pravni okvir vezan uz pouzdanost (safety) odnosno sigurnost (security) opskrbe, a donesena je nakon rusko-bjeloruske plinske krize 2004. godine. ${ }^{15}$ Fokus Direktive je na ekonomskoj dimenziji, na rastu ovisnosti EU-a o uvozu, no sadrži i pravila za slučaj "velike krize opskrbe", definirane kao situacije u kojoj EU riskira izgubiti više od 20\% opskrbe plinom iz trećih država. Jedan od kriterija proglašenja velike krize opskrbe pretpostavlja primjenu principa subsidijarnosti - kriterij je da se na razini EU-a ne može adekvatno upravljati nacionalnim mjerama, što upućuje na želju da se, koliko je to moguće, zadrži primat tržišta jer su tržišni igrači u energetskoj trgovini energetska poduzeća na nacionalnoj razini. ${ }^{16}$ Najprije se razvijao mehanizam ranog upozorenja (nadzor i analiza stanja na plinskom tržištu, godišnja izvješća o stanju na nacionalnom tržištu, preventivni akcijski planovi i planovi za hitne situacije), ${ }^{17}$ a nakon druge plinske krize i mehanizam za suzbijanje rizika preko za sve države članice automatski obvezujuće Uredbe o mjerama osiguranja sigurnosti opskrbe (EP/EV, 2010). Mehanizam razlikuje dvije vrste mjera - za prevenciju krize i za ublažavanje posljedica izvanrednih kriznih situacija, a kako bi se zadržao primat tržišta, kriza se proglašava u tri stupnja: nakon "ranog upozorenja" slijedi proglašenje "opasnosti", a "hitnost" se može proglasiti tek kada su sve tržišne mjere iscrpljene, ali nisu dostatne. Kako se ispostavilo da nije problem samo agregirani manjak plina, nego i nepovezanost infrastrukture,

rizikofikacija (Riskification) upotrijebio je Olaf Corry u svom radu iz 2012. "Securitisation and 'riskification': Second-order security and the politics of climate change” želeći ukazati na potrebu da se odgovore na rizike ne naziva prečesto upotrebljavanim terminom sekuritizacija.

15 Tada je eskalirao rusko-bjeloruski spor oko cijene plina i pokušaja RF-a da preuzme kontrolu nad bjeloruskom plinskom mrežom kojom je ruski plin tranzitirao prema Europi, a rezultat je bio šestomjesečni prekid opskrbe ruskim plinom Bjelorusije, što EU nije bitno osjetio jer je preko Bjelorusije transportirana manja količina ruskog plina prema EU-u (20\%). Tek su rusko-ukrajinske plinske krize 2006. i 2009. imale materijalan (EU je ostao bez plina) i perceptivan učinak (plinska trgovina s EU-om prestala je biti dio privilegirane suradnje i postala problem).

${ }^{16}$ U slučaju velike krize opskrbe aktivira se mehanizam koji ima tri stupnja: prvo djeluju energetska poduzeća kao tržišni igrači na nacionalnoj razini, na kojoj po potrebi dijele odgovornost $\mathrm{s}$ državom, a na razini EU-a s EK-om, koji ima kompetencije limitirane na savjetovanje, preporučivanje mjera i nadzor implementacije.

${ }^{17}$ Nakon prve plinske krize EV je 2006. osnovao Mrežu korespondenata za energetsku sigurnost / NESCO sa zadatkom prikupljanja informacija o vanjskim čimbenicima i izdavanja ranog upozorenja; 2007. je na inicijativu EK osnovan Ured za promatranje energetske situacije (EOO) radi praćenja modela potražnje i opskrbe na tržištu EU-a, identifikacije nedostataka infrastrukture i opskrbe u ranoj fazi; 2009. EP i EV potvrdili su Plinsku direktivu koja je obvezala države članice na dostavljanje EK-u godišnjih izvješća o stanju na nacionalnom energetskom tržištu, a EK je dobio pravo proglasiti hitno stanje na razini EU-a ili neke regije EU-a. 
Uredba sadrži i prvu normativno-tehničku mjeru - tzv. N-1 standard, indeks plinske sigurnosti, koji služi kao mjerilo za procjenu ima li država dovoljno kapaciteta da zadovolji ukupnu potrošnju plina u slučaju prekida pojedinačno najveće plinske infrastrukture na dan izrazito velike potrošnje. Nezadovoljenje standarda pretpostavlja fizičku izgradnju neophodne infrastrukture, najčešće su to reverzibilne interkonekcije (osobito na pravcu Sjever-Jug) kao materijalni preduvjet fizički integriranog plinskog tržišta i jačanja otpornosti plinskog sustava, kao i primjene načela solidarnosti te kasnije definirane obveze na regionalnu suradnju.

Primjena principa solidarnosti u energetskim pitanjima nije bila samorazumljiva. Solidarnost pretpostavlja kolektivnu akciju, što se može shvatiti kao svojevrsno udruživanje država članica uvoznica plina, a to je iz perspektive liberalne ekonomije kartel i doprinosi slabljenju kompetitivnog tržišta, pa je nekonzistentno s nastojanjima EK da osnaži liberalizirano i kompetitivno energetsko tržište EU-a. Tek se Lisabonski ugovor iz 2009., prvi temeljni zakonski dokument EU-a koji je imao posebno poglavlje posvećeno energetskim pitanjima, poziva na "duh solidarnosti između država članica" (bez spominjanja vojnih mjera, konfrontacije, antiruskih elemenata), no primjena principa solidarnosti ostala je pitanje interpretacije jer je izostalo pravno obvezivanje. Prvi put primjenu principa solidarnosti u energetskim pitanjima jasno definira tek 2017. Uredba o mjerama osiguranja sigurnosti opskrbe plinom (EP/EV, 2017). Uredba je obvezala države članice na pomoć državi s kojom direktno graniče u slučaju velike krize opskrbe plinom, a prema kriterijima razine međusobne povezanosti i zrelosti tržišta dizajnirane su transnacionalne regije, nazvane "plinske grupe". Tako je EU, kako bi umanjio materijalnu i percipiranu prijetnju od prekida opskrbe, u svoju energetsku politiku ipak postupno uveo koncept kolektivne akcije, mehanizam solidarnosti kao viši stupanj od mehanizma koordinacije.

Krajnji je cilj rizikofikacijskih mjera minimizirati troškove obustave opskrbe, no fokus nije na ekonomskoj učinkovitosti plinske trgovine, nego na jačanju otpornosti plinskog sustava strateškim skladištenjem ${ }^{18} \mathrm{i}$ integracijom unutarnje plinske infrastrukture. Rizikofikacijske mjere EU-a mogu se nazvati ekonomskima zbog potencijala da smanje jako visoke troškove krizne zamjene izvora, pravca dobave ili vrste energenta, ali nikako nisu slobodnotržišne, jer pretpostavljaju direktne intervencije na tržište. Otpornost, kao i sigurnost, pretpostavlja žrtvovanje ekonomske učinkovitosti i zbog određenog stupnja infrastrukturne redundantnosti (tzv. spava-

${ }^{18}$ Plinska skladišta obično služe za pokrivanje peakova, optimalnu utilizaciju plinske infrastrukture i koriste se u komercijalnim strategijama. Dugoročna mjera ublažavanja posljedica krize vanjske opskrbe pretpostavlja gradnju strateških skladišta, koja su skuplja od naftnih zbog agregatnog stanja plina, a kako su razlike u nacionalnim kapacitetima skladišta velike, ne obvezuje na definirani udio strateških zaliha plina. 
jućih plinovoda) traži potporu financijskih instrumenata s razine EU-a kao izvantržišnu mjeru; kako bi se osigurala minimalna logika tržišnog pristupa, potpora se dodjeljuje tek u slučaju kada ekonomska neučinkovitost odvraća privatne investitore. U rizikofikacijske mjere EU je prvotno pokušao uključiti RF: u okviru Energetskog dijaloga EU-a i RF-a, pokrenutog 2006. na sastanku na vrhu EU-a i RF-a u Parizu, dogovoren je 2007. Mehanizam ranog upozorenja, skup procedura o obostranoj razmjeni informacija o potencijalnim problemima i načinima njihova rješavanja, koji je, međutim, ignoriran tijekom druge plinske krize 2009. godine. ${ }^{19}$

Rizikofikacijske mjere su normativno-tehničke mjere, unaprijed dogovorene i standardizirane procedure $\mathrm{i}$ investicije $\mathrm{u}$ fizičku infrastrukturu (uspostava procedura za nadzor i analizu stanja na plinskom tržištu, kao i za postupanje u slučaju kriza, skladištenje, reverzibilne interkonekcije, jačanje koncepta solidarnosti, standard $\mathrm{N}-1$ itd.). U te se mjere mogu ubrojiti i javnopolitičke mjere regulatorne prirode, koje povećanjem energetske učinkovitosti i korištenjem obnovljivih izvora energije ciljaju na promjenu modela potražnje, mogu podići sigurnost opskrbe i također su tržišno neodržive ${ }^{20}$ Kako je sigurna opskrba plinom javno dobro, rizikofikacije mjere imaju političko opravdanje - odvraćanje potencijalnih uzročnika plinskih kriza, i ekonomsko opravdanje - očuvanje autonomije tržišnih sudionika i funkcioniranje liberalnog tržišta, no u prvom su redu netržišne mjere jer pretpostavljaju selektivne intervencije u unutarnje tržište u cilju utjecanja na vanjske prijetnje, ukazujući istodobno na povezanost unutarnje i vanjske dimenzije energetske politike. Rizikofikacijske mjere odnose se na aktivnosti na strani potražnje, ciljaju na jačanje otpornosti unutarnjeg plinskog sustava EU-a stvaranjem sigurnosne margine, "sigurnosnog tampona unutar sustava protiv šokova te potencijala za oporavak sustava" (Yergin, 2006, str. 76) i koordinira ih EK. Iz rizikofikacijske perspektive plinska trgovina se sagledava kao izvor rizika, a rizikofikacijske mjere omogućuju brz odgovor na prekid, daju sposobnost upravljanja na određeno vrijeme vanjskim utjecajima koje samo tržište ne može ukloniti ili uravnotežiti te tako kratkoročno jamče kontinuitet ekonomskih i društvenih aktivnosti i ostavljaju vremena za dugoročniju reakciju. $\mathrm{U}$ tom smislu pozitivno utječu na pouzdanost opskrbe, ali ne i na političku sigurnost jer ne mogu ponovno uspostaviti ravnotežu međuovisnosti u

19 Energetski dijalog je nakon krimske krize praktično obustavljen. U međuvremenu je u okviru Dijaloga 2011. osnovano Savjetodavno plinsko vijeće EU-a i RF-a za procjenu trendova i posljedično smanjenje rizika i suradnju, koje, međutim, nikada nije zaživjelo. Dvije godine kasnije EK i Vlada RF-a objavili su dokument Putokaz za energetsku suradnju EU-a i Rusije do 2050. godine, koji nije rezultirao pravno obvezujućim zaključcima jer se temeljio na zajedničkim interesima, ali ne i na zajedničkim idejama, vrijednostima i identitetima.

${ }^{20}$ I okolišna dimenzija energetske politike traži izvantržišne financijske potpore, no razlika je u tome što u vezi s okolišnom dimenzijom postoji do sada neviđena razina suglasnosti u EU-u, dok u vezi sa sigurnosnom dimenzijom energetske politike postoje snažni nacionalni otpori. 
plinskom odnosu. Za EU je bilo važnije spriječiti manipuliranje tržištem i njegovo monopoliziranje kako bi se smanjila asimetrija međuovisnosti; ruske geoekonomske i geopolitičke aktivnosti tražile su odgovore orijentirane na sigurnost, a ne na učinkovitije funkcioniranje tržišta i upravljanje tržišnim rizicima.

EU je bio svjestan nemogućnosti eliminacije plinskog odnosa s RF-om i potrebe da, u cilju dugoročnog povećanja energetske sigurnosti, vrati ravnotežu međuovisnosti ili barem bitno reducira asimetriju u tom odnosu. Pokušava nadoknaditi nemogućnost supstitucije i ključna postaje diversifikacijska politika (Uredba o mjerama osiguranja sigurnosti opskrbe plinom, EP/EV, 2010), tj. diversifikacija izvora i pravaca opskrbe plinom: izgradnja plinovoda izvan teritorija i kontrole RF-a, koji će se puniti iz neruskih izvora, i LNG terminala, koji također omogućuju uvoz neruskog plina i imaju fleksibilan pravac transporta. Diversifikacija je samo uvjetno ekonomska mjera usmjerena prema van u smislu da umanjuje ruski monopol u plinskoj trgovini i na plinskom tržištu EU-a, što otežava manipulaciju cijenom, no ekonomska učinkovitost ni u kom slučaju nije ključno obilježje diversifikacijske politike. Diversifikacijska politika znači direktnu intervenciju na tržište: rješenje vidi u izgradnji tržišno neodržive energetske infrastrukture, koja je iz ekonomske perspektive tek suboptimalno rješenje, $i$ to u slučaju kada utječe na smanjenje cijene plina. To je svakako netržišno rješenje koje, kao i fizička integracija plinske infrastrukture unutar EU-a (reverzibilne interkonekcije), pretpostavlja toleriranje određenog stupnja neučinkovite redundantnosti čak i u odsustvu prijetnje. Riječ je o tzv. pojačivačima sigurnosti koji su po definiciji neučinkoviti, traže financijsku potporu i podupiru se financijskim instrumentima EU-a.

Diversifikacijski projekti nisu komercijalni, nego strateški projekti na razini EU-a i ekonomski je trošak preduvjet osiguranja dugoročnog sigurnosnog cilja EU-a; riječ je o oportunitetnom trošku jer svako diversifikacijsko rješenje znači određeni financijski gubitak u odnosu na početno rješenje. Diversifikacijska politika može se smatrati političkom mjerom jer joj je cilj umanjiti mogućnost ruskog korištenja plinske trgovine kao instrumenta moći. EU u službenim dokumentima većinom ne koristi izravnu antirusku političku retoriku, nego ukazuje na potrebu smanjenja uvoza u EU energenata općenito. Međutim, na stvarne razloge upućuje $R e$ zolucija Europskog parlamenta iz 2012. prema kojoj "diversifikacija podrazumijeva neruske izvore nafte, plina i električne energije za države članice koje su preovisne o jednom opskrbljivaču, jer ruski plin čini od 48 do $100 \%$ potrošnje plina u 12 od 27 država članica i ima direktan utjecaj na energetsku sigurnost EU-a" (EP, 2012; istaknula a.). Kada je postalo važno čiji je plin, postalo je jasno da je i u EU-u riječ o politizaciji, koja potkopava pristup "tržišta i institucija” (Correljé i Van der Linde, 2006), da je riječ o geopolitičkoj diversifikaciji, te je diversifikacijski diskurs zamijenio integracijski. 


\section{Neekonomski odgovori EU-a}

Dok je diversifikacijska politika EU-a prijelazno rješenje između ekonomskih i neekonomskih odgovora EU-a na rusku politizaciju plinske trgovine, pokušaji sekuritizacije i u konačnici politizacija te trgovine u EU-u jednoznačno su neekonomski odgovori. Istodobno s ostalim načinima prilagodbe EU-a tekli su, na poticaj i uz potporu SAD-a, pokušaji novih i o ruskom plinu ovisnijih država članica EU-a da sekuritiziraju plinsku trgovinu, da diskurzivnim putem trgovinski odnos i pitanje niske politike prevedu u područje sigurnosti i učine ga pitanjem visoke politike. Pripadnici Kopenhaške škole sigurnosnih studija, tvorci teorije sekuritizacije, ${ }^{21}$ razlikuju politizirana pitanja, koja su dio javnih politika i traže reakciju vlade u smislu odlučivanja i alokacije sredstava, od sekuritiziranih pitanja, koja su izložena egzistencijalnoj prijetnji i traže odgovore jednake po hitnosti i opsegu onima na tradicionalne, vojne prijetnje te djelovanje izvan standardne procedure, izvan "normalne" politike. Trgovinskim pitanjima tradicionalno se pristupa kao nepolitičkima, no kako je plinska trgovina između EU-a i RF-a od samog početka bila predmet odluka vlada, ispravnije je reći da je iz tradicionalne, realističke perspektive bila pitanje ekonomske, niske politike. U pokušajima sekuritizacije te trgovine traženo je da se u EU-u, u slučaju prijetnje prekidom ili prekida opskrbe plinom, primjeni princip solidarnosti; zagovaralo se poduzimanje kolektivne akcije pozivajući se na primjer odredbe iz čl. 5. Ugovora o NATO-u, a njezina politizacija znači da je postala pitanje strateškog, političkog odlučivanja i visoke politike.

U sekuritizacijskim pokušajima predlagao se "energetski NATO" (Marcinkiewicz, 2006), ${ }^{22}$ prekid opskrbe ili prijetnju prekidom izjednačavalo se s primjenom sile ili s prijetnjom silom i tražilo se međusobno obvezivanje na solidarnu obranu od vanjskih opskrbljivača, mehanizam uzajamne pomoći. Bio je to prijedlog primjene koncepta kolektivne sigurnosti na plinska pitanja, a diskurzivna konstrukcija plinske trgovine kao sigurnosnog pitanja gradila se uz pomoć argumenta o asimetričnoj međuovisnosti na temelju koje RF nastoji ograničiti vanjskopolitički suverenitet, slobodu djelovanja EU-a; ${ }^{23}$ plinska trgovina s RF-om uokvirivala se

21 Buzan i suradnici (1998) razradili su teoriju sekuritizacije u radu "Security - a New Framework for Analysis".

${ }^{22}$ Poljska je preuzela ulogu glavnog sekuritizatora u EU-u, te je već u veljači 2006. poljski premijer Marcinkiewicz (2006) u Financial Timesu iznio prijedlog novog Europskog ugovora o energetskoj sigurnosti, svojevrsni pakt koji bi bio otvoren svim državama članicama EU-a i NATO-a koje kupuju ruski plin (samo 5 od 27 država članica EU-a nisu ujedno i članice NATO-a) i pozvao se pritom na Bruxelleski ugovor iz 1948. i Washingtonski ugovor iz 1949. godine. Prijed$\log$ je ponovio na sastanku Vijeća za transport, telekomunikacije i energiju EU-a (EC-PR, 2006). ${ }^{23}$ EP je u rezoluciji Stanje odnosa EU-RF iz lipnja 2015. (EP, 2015) ustvrdio da je “... energetska politika bitan element vanjske politike EU-a... (EU) podržava... bitno smanjivanje ovisnosti pojedinih država članica o vanjskim energetskim opskrbljivačima, osobito Rusiji... borbu protiv korištenju energenata kao aduta u političkim i diplomatskim pregovorima...". 
kao egzistencijalna prijetnja - doduše, ne fizičkom opstanku EU-a, nego suverenitetu kao minimalnoj nacionalnoj vrijednosti. ${ }^{24}$ Sekuritizatori su na plinsku trgovinu gledali iz perspektive solidarnosti i tražili konfrontaciju, dok su druge, uglavnom stare, velike i manje ovisne države članice zagovarale nacionalnu suverenost, zanemarivale sigurnosnu i naglašavale ekonomsku dimenziju te trgovine i tražile kooperativnost s RF-om. ${ }^{25}$

Sekuritizacija plinske trgovine između EU-a i RF-a nije uspjela, nije nastao slučaj sekuritizacije, jer nije došlo do intersubjektivnog razumijevanja u EU-u što plinska trgovina jest. Relevantna publika, a to su, kada je riječ o pitanju sigurnosti, sve države članice koje konsenzualno odlučuju u Europskom vijeću, nije pristala razumjeti plinsku trgovinu $\mathrm{s}$ RF-om u terminima klasične gramatike i realistične logike sigurnosti, kao prijetnju jednom od sektora sigurnosti EU-a. Nije to bila samo "liberalna desekuritizacija" u skladu s identitetom EU-a, odbijanje postmoderne integracije koja se odriče primjene sile da plinsku trgovinu uklopi u tradicionalno, vojno-političko shvaćanje sigurnosti. Važnija je bila osjetljivost EU-a u plinskoj trgovini s RF-om, isti čimbenik koji je olakšao njezino korištenje u politici moći i koji je u EU-u izazvao strah od ruske reakcije u vidu obustave opskrbe plinom i tako stvorio dilemu ovisnosti. Bio je to strah da će sigurnosni okvir proizvesti negativne posljedice za plinsku politiku i međusobnu plinsku trgovinu. Nije nastao slučaj sekuritizacije, iako zadržavanje diskursa energetska sigurnost ukazuje na mogućnost da je sekuritizacija latentno u tijeku, ${ }^{26}$ osobito nakon ukrajinske krize 2014. koja je pogoršala i političke odnose između EU-a i RF-a te pojačala percepciju RF-a kao prijetnje, ${ }^{27}$ tim više što je sekuritizacija stvar političkog izbora.

Pokušaji sekuritizacije i politizacija plinske trgovine u EU-u kao jednoznačno neekonomski odgovori pripadaju paradigmi "regije i carstva" (Correljé i Van der Linde, 2006). Povezuje ih koncept moći: politizacija je povezivanje vanjskotrgo-

${ }^{24}$ Diskurzivna konstrukcija plinske trgovine s RF-om kao egzistencijalne prijetnje učestala je nakon ukrajinske krize 2014.: primjerice, direktor Glavnog tajništva Energetske zajednice (okuplja države članice EU-a i države kandidate iz crnomorske regije i jugoistočne Europe) Janez Kopač (STA, 2014) izjavio je da "Rusija koristi plin kao oružje".

25 Primjerice, ministar vanjskih poslova SRNJ Frank-Walter Steinmeier (2006) se umjesto sustava kolektivne energetske sigurnosti založio za "koncept kooperativne sigurnosti", koji bi uključivao i RF.

${ }^{26}$ Prema McDonaldu (2008, str. 76), sekuritizacija “nije jedan jedinstveni trenutak, pojedinačni govorni čin, nego kontinuirani proces u kojem sudjeluju različiti akteri”.

27 Snažno se promijenio i diskurs EU-a, doduše za sada u neobvezujućim dokumentima EU-a. Tako EP poziva da EU, koji je ranije RF smatrao suradnikom, "kritički revidira svoje odnose s Rusijom, što uključuje... plan suprotstavljanja agresivnim i razdvajajućim politikama koje provodi Rusija... (koja stoga) ne može više biti tretirana ili smatrana 'strateškim partnerom"' (EP, 2015). 
vinskog odnosa s vanjskom politikom preko njegova korištenja kao instrumenta moći u cilju jačanja moći utjecanja, a sekuritizacija pretpostavlja dovođenje ekonomskog odnosa u područje nacionalne sigurnosti preko diskursa moći. ${ }^{28}$ Kako je izostala performativna dimenzija sekuritizacije, plinska trgovina je u materijalnom smislu ostala nedirnuta, no kao ostatak diskurzivne dimenzije neuspjele sekuritizacije u diskurzivnom je smislu postala energetska sigurnost. Sekuritizacijski su koraci odigrali i ulogu katalizatora određenih procesa u EU-u: potaknuli su dovršetak procesa komunitizacije energetskih politika država članica EU-a, stvoren je EP EU i povezan sa zajedničkom vanjskom i sigurnosnom politikom (ZVSP) EU-a, a prethodno liberalno-ekonomski identitet EU-a utjecao je na to da ekonomska perspektiva dominira nad političkom i tako izolira plinsku trgovinu od vanjske politike. Osobito nakon ukrajinske krize, koja je pogoršala političke odnose EU-a i RF-a, zagovara se integracija vanjske dimenzije energetske politike EU-a s vanjskopolitičkim ciljevima i promovira koncept energetske diplomacije EU-a - ne više isključivo na nacionalnoj razini, nego i na razini EU-a - kao instrument agregirane tržišne i političke moći EU-a. ${ }^{29}$ Radi jačanja sigurnosne dimenzije EP EU-a 2015. je zajednička energetska politika EU-a krenula i prema većem stupnju integracije stvaranjem Europske energetske unije (EEU), kojoj je glavni cilj, uz institucionalno organiziranje, jačanje solidarnosti, osnaživanje kompetencija EK, povezivanje EP EU-a sa ZVSP-om i jačanje energetske sigurnosti, čija bi eksternalija mogla biti jačanje europske integracije općenito. ${ }^{30}$

EK je bio uspješan "politički poduzetnik" ${ }^{31}$ koji je povezao problem (povećanu ovisnost o uvozu ruskog plina), događaj (plinske krize) i rješenje (integriranu unutarnju dimenziju EP EU-a) kako bi ojačao svoju ulogu u vanjskoj dimenziji EP EU-a i komunitizirao je u smislu kolektivnog vanjskog djelovanja država članica u energetskim pitanjima pod vodstvom EK, uokvirujući svoj prijedlog ekonomski - tvrdeći da bilateralni odnosi ne jačaju kompetitivnost i sigurnost opskrbe, nego fragmentiraju unutarnje tržište. EK je stekao moć uključivanja u međudržavne od-

${ }^{28}$ Prema Buzanu i suradnicima (1998, str. 21) "kada govorimo o sigurnosti u međunarodnim odnosima, taj pojam dobiva ekstremno značenje i ima korijene upravo u politici moći”.

${ }^{29}$ Energetska diplomacija iz perspektive RF-a znači korištenje energenata za realizaciju vanjskopolitičkih ciljeva, a iz perspektive EU-a znači učiniti energetska pitanja dijelom zajedničke trgovine politike i zajedničke vanjske i sigurnosne politike. To je u EU-u išlo sporo jer nije bilo u skladu s liberalno-ekonomskim modelom, iako je u stvarnom svijetu izostanak energetske diplomacije EU-a značio izostanak kohezije i slabost diplomatskih mjera EU-a. Vijeće EU-a je u srpnju 2015. ipak donijelo Zaključak o energetskoj diplomaciji (Vijeće EU-a, 2015).

${ }^{30}$ Raines i Tomlinson (2016), Braun (2011) i Fiedler (2015) smatraju da bi EEU mogao imati pozitivan učinak prelijevanja na ZVSP.

${ }^{31}$ Politički poduzetnici su, prema Kingdonu (2003, str. 204), akteri spremni investirati resurse kako bi zauzvrat dobili javnu politiku koju žele. 
nose u energetskim pitanjima - doduše, samo na tehničkoj razini, jer u vanjskoj dimenziji EP EU-a nacionalni interesi i bilateralni dogovori još uvijek imaju prioritet pred kolektivnim rješenjima: čl. 194.2. Ugovora iz Lisabona propisuje da "države članice EU-a samostalno određuju uvjete za iskorištavanje svojih energetskih resursa, odabiru energetsku mješavinu i određuju opću strukturu energetske opskrbe". ${ }^{32}$

Iako je energetsko područje i nadalje područje podijeljene odgovornosti između institucija EU-a i država članica, tek rođeni EP EU snažno je utjecao na identitet EU-a - na povlačenje dominantnog liberalno-ekonomskog identiteta - i EU je, poput RF-a, počeo u plinskoj trgovini prihvaćati ekonomsku neučinkovitost i davati prednost političkim pred ekonomskim kriterijima. Europska komisija, kao jedina istinski supranacionalna institucija EU-a i izvorno promotor tržišnog pristupa, postala je zagovornik politizacije plinske trgovine, što predstavlja vraćanje države u ekonomiju i donošenje odluka na temelju političkih motiva, a ne ekonomske učinkovitosti, pa je EK, povećavajući svoje ovlasti u energetskoj politici, usporedo postao i katalizator dugoročne energetske sigurnosti. Politizacija u slučaju plinske trgovine između EU-a i RF-a primjer je da sekuritizacija nije nužno nastavak politizacije: u slučaju plinske trgovine s RF-om politizacija je i ishodište i eksternalija sekuritizacijskih koraka EU-a.

Pokušaji sekuritizacije i pogoršanje političkih odnosa s RF-om potaknuli su EU 2014. na donošenje prvog strateškog dokumenta posvećenog isključivo energetskoj sigurnosti - Strategije europske energetske sigurnosti, koja ima "naglašeno geopolitički ton bez presedana na razini EU-a" (Youngs, 2014, prema Szulecki, 2018, str. 3). O politizaciji na razini EU-a svjedoče i dva pravna dokumenta EU-a:

- Uredba o kontroli stranih ulaganja (EP/EV, 2019), koja je pravno obvezujuća za sve države članice i u okviru posebne strukture predviđa uspostavu mehanizma za suradnju država članica i EK te davanje procjena o postojanju prijetnje u smislu stranog ulaganja s političkom pozadinom (od listopada 2020.). Procjene su savjetodavnog karaktera, osim kada je riječ o prijetnji nacionalnoj sigurnosti ili javnom poretku više država članica. EK je u svojim medijskim objavama izrijekom spomenuo da je riječ o ulaganjima iz Kine, Ujedinjenih Arapskih Emirata i RF-a (EC-PR, 2019). Odgovor je to "istom mjerom" na ruski Zakon o strateškim investicijama iz 2008. koji je imao isti cilj - suzbiti prijetnju od nekontroliranog priljeva stranih investicija u strateške sektore iz razloga nacionalne sigurnosti.

- Revidirana Direktiva o zajedničkim pravilima za unutarnje plinsko tržište (EP/EV, 2019a), koja osigurava primjenu pravila unutarnjeg energetskog tr-

32 EU optužuje RF za segmentiranje plinskog tržišta EU-a, koje u stvarnosti nije integrirano, pa države članice suvereno određuju strategiju opskrbe. 
žišta, u prvom redu pravo pristupa trećih strana i na plinovode između država članica i trećih država, a kako bi se ispravio pravni vakuum - ranija Direktiva donesena 2009. u sklopu Trećeg energetskog paketa (TEP) EU-a odnosila se samo na onshore, a revidirana obuhvaća i offshore plinovode. Kako je to ekonomski neracionalna odluka, jer na ishodišnoj točci osim RF-a nema trećih strana koje bi mogle ponuditi plin, možda su u pravu oni koji Direktivu nazivaju "Zakon Sjeverni tok 2" i tvrde da ima politički cilj: diskriminirati i obeshrabriti taj projekt te ograničiti utjecaj RF-a. Revizija Direktive ukazuje na to da EU svoj mehanizam, izvorno dizajniran za stvaranje i upravljanje integriranim internim plinskim tržištem, koristi u politizaciji plinske trgovine s RF-om.

Pristup institucija EU-a spornom projektu izgradnje ruskog plinovoda Sjeverni tok 2 (ST2), kao nadogradnje plinovoda ST1, koji je prvi put direktno povezao RF kao izvoznika i SRNJ kao uvoznika plina uz zaobilaženje tranzitnih država (kojima RF mora plaćati tranzitne pristojbe i koje mogu politički motivirano ometati transport plina i tako utjecati na opskrbu SRNJ ruskim plinom), također ukazuje na promjenu perspektive u pogledu plinske trgovine s razine EU-a. Svojedobno je EK podržavao izgradnju ST1, uvrstivši ga 2000. i 2006. u TEN-E ${ }^{33}$ projekte kao dio napora EU-a da diversificira opskrbu energentima, sufinanciravši studiju izvodivosti projekta te odobrivši djelomično izuzeće od TEP-a, ne prihvaćajući argumente novih država članica (npr. Poljske i Slovačke) da ima geopolitički cilj. Plinovod ST1 je u materijalnom smislu povećao pouzdanost opskrbe EU-a, zaobišavši problematičnu tranzitnu državu Ukrajinu, no osnažio je percepciju o plinskoj trgovini s RF-om kao prijetnji sigurnosti jer je ojačao moć ruskog plinskog instrumenta, omogućivši vjerodostojniju prijetnju prekidom opskrbe koja se ne bi odnosila na stare države članice EU-a. Nakon ukrajinske krize 2014. institucije EU-a priklonile su se novim, slabijim državama članicama EU-a zauzevši prema ST2 pristup "regije i carstva" te označivši zagovaranje i ekonomsko uokvirivanje projekta u RF-u i u staroj i najvećoj državi članici SRNJ, neovisno o pogoršanim političkim odnosima, kao miješanje ekonomije u sigurnost. EK je oštro reagirao već na najavu gradnje ST2 2015., a naknadno su i druge institucije EU-a projektu dale politički okvir. Primjerice, predsjednik EV-a D. Tusk izjavio je 2017. da "ne služi europskim interesima" (u pismu predsjedniku EK Junckeru; Baczynska, 2017), a 2018. je EP, u Rezoluciji o provedbi Sporazuma o pridruživanju između EU-a i Ukrajine, projekt nazvao "političkim projektom" i "prijetnjom europskoj energetskoj sigurnosti" (EP, 2018). Da EU odgovara istom mjerom na rusko korištenje plinske trgovine u

33 Transeuropske mreže osmišljene su na temelju Rimskih ugovora iz 1957. i odnose se na tri vrste mreža: TEN-E (energetske), TEN-T (transportne) i eTEN (telekomunikacijske). Cilj im je bio stvaranje unutarnjeg tržišta te jačanje ekonomske i socijalne kohezije u EU-u. 
politici moći svjedoči i izjava visokog predstavnika EU-a za zajedničku vanjsku i sigurnosnu politiku Josepa Borrella (2020) da Europljani moraju "vidjeti svijet kakav jest, a ne kakav su se nadali da jest... svijet geopolitičkog nadmetanja... (koji) pojačano karakterizira sirova politika moći... (i u kojem su) ekonomski i drugi interesi militarizirani... (EU) mora ponovno naučiti jezik moći...".

\section{Zaključak}

Odgovor EU-a na rusku politizaciju plinske trgovine hibridni je model, kojim EU nastoji istodobno ispuniti teško pomirljive ciljeve. U tom hibridnom modelu plinska trgovina dobiva jednom ekonomski, drugi put sigurnosni okvir, iako ti različiti okviri mogu za posljedicu imati dijametralno suprotna rješenja. Kada je plinska trgovina s RF-om uokvirena ekonomski, ona je predmet interesa energetske politike ili šre ekonomske politike kao javne politike, koja plin tretira kao robu; fokus je na pouzdanoj i cjenovno prihvatljivoj opskrbi i maksimiziranju profita. Kada joj se dodijeli političko-sigurnosni okvir, cilj postaje maksimizirati (u slučaju RF-a), odnosno minimizirati (u slučaju EU-a) ovisnost iz koje proizlazi moć. Realizacija tog cilja uključuje oportunitetni trošak, koji je teško prihvatljiv kada je riječ o nevojnim prijetnjama, ali na koji je EU primoran pristati ukoliko želi umanjiti ono što doživljava kao prijetnju svom vanjskom suverenitetu. Stoga je EU u konačnici i sam bio prisiljen, u cilju jačanja svoje energetske sigurnosti, zadržati ranije donesene ekonomske (tržišne i netržišne), diversifikacijske i rizikofikacijske mjere te ih nadograditi politizacijom plinske trgovine, koja daje prednost strateškom okviru pred komercijalnim.

Promjena uloge plinske trgovine u odnosima između EU-a i RF-a dobar je indikator povlačenja liberalno-ekonomskog identiteta EU-a u korist realističkog, više geopolitičkog. Liberalno-ekonomski identitet proizveo je ideju o pozitivnoj ekonomskoj međuovisnosti i priječio EU da vidi "đavolji potencijal” međuovisnosti, koji je jednu od strana motivirao da manevrira kako bi promijenila ravnotežu međuovisnosti i uspostavila odnos moći. EU se postupno prilagodio realističko-političkoj paradigmi u plinskim poslovima i, protivno svom identitetu, vratio državu i politiku u ekonomiju. Geopolitičkim postavljanjem EU je sam srušio iluziju o međuovisnosti kao izvoru stabilnosti i sigurnosti, a to što dužnosnici EU-a (kao i RF-a) javno i nadalje inzistiraju na međuovisnosti, upućuje na to da je plinska trgovina važna za EU zbog kratkoročne osjetljivosti i potencijalne dugoročne ranjivosti, kao i zbog nepostojanja vjerodostojne alternative.

Inzistiranje na konceptu vanjskog suvereniteta u smislu nezavisnosti od bilo kakve izvanjske, tuđe vlasti ukazuje na povećanje geopolitičkog identiteta EU-a. Dok je cilj "projekta EU" izvorno bio stjecanje unutarnjeg suvereniteta, neograničene vlasti nad članovima političke zajednice preko ograničavanja i preuzimanja 
kontrole nad suverenitetom država članica kako bi ih pacificirao (vidi Jović, 2018, str. 378), EU danas postaje geopolitički akter u međunarodnim odnosima koji nastoji voditi suverenističku politiku i uspostaviti svoj vanjski suverenitet. Uspostava hibridnog modela kojim EU odgovara na rusku politizaciju međusobne plinske trgovine doprinijela je slabljenju "liberalnog projekta", ali i uspostavi vanjskog suverenizma EU-a. Ovaj rad ostavio je otvorenim za daljnje istraživanje pitanje u kojoj mjeri pokušaji SAD-a da utječe na EP EU i na plinski odnos EU-RF (primjerice, uvođenjem eksteritorijalnih sankcija za europska poduzeća koja sudjeluju u realizaciji ST2) također osnažuju želju za uspostavom europskog suvereniteta.

\section{LITERATURA}

Baczynska, G. (2017). EU's Tusk criticises Nord Stream 2 as Brussels readies for Russia talks. Preuzeto 14. 8. 2019. s: Reuters, https://de.reuters.com/article/uk-eunordstream2-tusk- idUKKBN18Z2ON

Barbieri, K. (2002). The Liberal Illusion - Does Trade Promote Peace? University of Michigan Press. Michigan.

Borrell, J. (2020). Embracing Europe's Power. Preuzeto 30. 3. 2020. s: Project Sindicate, https://www.project-syndicate.org/commentary/embracing-europe-s-powerby-josep-borrell-2020-02?barrier=accesspaylog

Braun, J. F. (2011). EU Energy Policy under the Treaty of Lisbon Rules - Beetwen a new policy and business as usual. EPIN. Brussells.

Buzan, B. i Wæver, O. (2003). Regions and Powers: The Structure of International Security. Cambridge University Press. Cambridge.

Buzan, B., Wæver, O. i de Wilde, J. (1998). Security - a New Framework for Analysis. Lynne Rienner Publishers. London.

Ciuta, F. (2010). Conceptual Notes on Energy Security: Total or Banal Security? Security Dialogue, 41 (2): 123-144.

Correljé, A. i Van der Linde, C. (2006). Energy supply security and geopolitics: A European perspective. Energy Policy, 34 (5): 532-543.

EC-PR (EC-Press Release). (2006). PRESS RELEASE 717th Council Meeting Transport, Telecommunications and Energy. Preuzeto 15. 1. 2017. s: European Commission Press Release Database, https://europa.eu/rapid/press-release_PRES-06-67_en.htm

EC-PR. (2019). Foreign direct investment report: continuous rise of foreign ownership of European companies in key sectors. Preuzeto 27. 9. 2019. s: EC-Press Release, https://ec.europa.eu/commission/presscorner/detail/en/IP_19_1668 
EC-PR. (2019a). The von der Leyen Commission: for a Union that strives for more. Preuzeto 15. 1. 2020. s: EC-Press Release, https://ec.europa.eu/commission/presscorner/detail/en/IP_19_5542

Emerson, R. (1962). Power-Dependence Relations. American Sociological Review, (27) 1: 31-41.

EP. (2012). European Parliament Resolution on Engaging in energy policy cooperation with partners beyond our borders: A strategic approach to secure, sustainable and competitive energy supply. 2012/2029 (INI). Preuzeto 29. 9. 2018. s: EUR-Lex, https://eur-lex.europa.eu/legal-content/EN/TXT/?uri=celex\%3A52012IP0238

EP. (2015). State of EU-Russia relations. Preuzeto 30. 4. 2018. s: European Parliament, https://www.europarl.europa.eu/doceo/document/TA-8-2015-0225_EN.html?redirect

EP. (2018). European Parliament resolution of 12 December 2018 on the implementation of the EU Association Agreement with Ukraine. 2017/2283 (INI). Preuzeto 3. 12. 2019. s: European Parliament, http://www.europarl.europa.eu/doceo/document/ TA-8-2018-0518_EN.html

EP/EV. (2010). Regulation (EU) No 994/2010 of the European Parliament and of the Council concerning measures to safeguard security of gas supply and repealing Council Directive 2004/67/EC. L 295/1. Preuzeto 3. 6. 2017. s: EUR-Lex, http:// eur-lex.europa.eu/legal-content/EN/ALL/?uri=CELEX\%3A32010R0994

EP/EV. (2017). REGULATION (EU) 2017/1938 concerning measures to safeguard the security of gas supply and repealing Regulation (EU) No 994/2010. L 280/1. Preuzeto 24. 3. 2019. s: EUR-Lex, https://eur-lex.europa.eu/legal-content/EN/TXT/ $\mathrm{PDF} /$ ?uri=CELEX:32017R1938\&iz=EN

EP/EV. (2019). Regulation (EU) 2019/452 of the European Parliament and of the Council of 19 March 2019 establishing a framework for the screening of foreign direct investments into the Union. LI 79/1. Preuzeto 25. 3. 2019. s: EUR-Lex, https://eurlex.europa.eu/legal-content/EN/TXT/?uri=CELEX:32019R0452

EP/EV. (2019a). Directive of the European Parliament and of the Council amending Directive 2009/73/EC concerning common rules for the internal market in natural gas. L 117/1. Preuzeto 24. 5. 2019. s: EUR-Lex, https://eur-lex.europa.eu/legal-content/EN/TXT/PDF/?uri=CELEX:32019L0692\&iz=EN

EU. (2012). TFEU. Consolidated versions of the Treaty on European Union and the Treaty on the Functioning of the European Union - Consolidated version of the Treaty on the Functioning of the European Union. Preuzeto 28. 2. 2018. s: EUR-Lex: https://eur-lex.europa.eu/legal-content/EN/TXT/?uri=celex\%3A12012E\%2FTXT

Fiedler, M. (2015). The Energy Union: what's behind it? Rosa Luxembrug Stiftung. Bruxelles.

Goldthau, A. i Sitter, N. (2014). A liberal Actor in a Realist World? The Commission and the external dimension of the single market for energy. Journal of European Public Policy, 21 (10): 1452-1472. 
Hirschman, A. O. (1980). National Power and the Structure of Foreign Trade. Pretisak, prošireno izd. University of California Press. Berkeley, Los Angeles, London.

Hrvatski jezični portal (n. d.). Hibrid. Preuzeto 7. 5. 2021. s: https://hjp.znanje.hr/index. php?show=search_by_id\&id=fV1jURc

Jeđud, I. (2007). Alisa u zemlji čudesa - kvalitativna metodologija i metoda utemeljene teorije. Hrvatska revija za rehabilitacijska istraživanja, 43 (2): 83-101.

Johnson, O. (2016). The Concept of Energy Security: Implications of EU-Russia Energy Relations, 2004-2012 (neobjavljena doktorska disertacija). The University of Leeds, School of Politics and International Studies. Leeds.

Jović, D. (2018). Europa izvan Europske unije? Nove dileme pri definiranju europskog identiteta. Revija za sociologiju, 48 (3): 359-394.

Juncker, J.-C. (2018). Rede zur Lage der Union 2018. Preuzeto 8. 2. 2020. s: Europäische Kommission, https://ec.europa.eu/commission/presscorner/detail/de/ SPEECH_18_5808

Kester, J. (2018). The Politics of Energy Security: Critical Security Studies, New Materialism and Governmentality. Routledge. Oxon, New York.

Kingdon, J. (2003). Agendas, Alernatives, and Public Policies. 2. izd. Longman. New York, London.

Kolodziej, E. A. (2005). Security and International Relations. Cambridge University Press. Cambridge.

Maas, H. (2020). Außenminister Maas zum heutigen Beginn der deutschen EU-Ratspräsidentschaft. Preuzeto 1. 8. 2020. s: Auswärtiges Amt, https://www.auswaertigesamt.de/de/newsroom/maas-deutsche-ratspraesidentschaft/2361154

Maas, H. (2020a). Rede von Außenminister Heiko Maas im Rahmen der vereinbarten Debatte im Deutschen Bundestag zum Beginn der deutschen EU-Ratspräsidentschaft. Preuzeto 2. 8. 2020. s: Auswärtiges Amt, https://www.auswaertiges-amt.de/de/ newsroom/maas-bt-ratspraesidentschaft/2361776

Marcinkiewicz, K. (2006). Europe's energy musketeers must stand together. Opinion World. Preuzeto 15. 6. 2017. s: Financial Times, https://www.ft.com/content/ fec8768c-999c-11da-a8c3-0000779e2340

McDonald, M. (2008). Constructivism. U: Wiliams, P. D. (ur.). Security Studies: an Introduction. Routledge. Abingdon, Oxon. str. 63-77.

Merriam-Webester (n. d.). Hybrid. Preuzeto 7. 5. 2021. s: https://www.merriam-webster. com/dictionary/hybrid?show $=0 \& \mathrm{t}=1402607220$ hybrid

Meyer, M. (2015). Between theory, method, and politics: positioning of the approaches to CDA. U: Wodak, R. i Meyer, M. (ur.). Methods of Critical Discourse Analysis. Sage Publication. London. str. 14-31.

Morgan, P. (2010). Sigurnost u međunarodnoj politici: tradicionalni pristupi. U: Collins, A. (ur.). Suvremene sigurnosne studije. Politička kultura i Centar za međunarodne i sigurnosne studije Fakulteta političkih znanosti u Zagrebu. Zagreb. str. 29-52. 
O'Sullivan, M. L. (2013). The Entanglement of Energy, Grand Strategy, and International Security. In: Goldthau, A. (ur.). The Handbook of Global Energy Policy. John Wiley \& Sons Ltd. West Sussex, UK. str. 30-47.

Prontera, A. (2017). The New Politics of Energy Security in the European Union and Beyond. States, Markets, Institutions. Routledge. London, New York.

Raines, T. i Tomlinson, S. (2016). Europe's Energy Union: Foreign Policy Implications for Energy Security, Climate and Competitiveness. The Royal Institute of International Affairs, Chatham House. London. Preuzeto 3. 7. 2016. s: https://www. chathamhouse.org/sites/files/chathamhouse/publications/research/2016-03-31-europe-energy-union-raines-tomlinson.pdf

STA. (2014). Ukraine Crisis Dominates Debate on SE Europe Cooperation. Preuzeto 5. 9. 2017. s: https://english.sta.si/2046013/ukraine-crisis-dominates-debate-on-seeurope-cooperation

Steinmeier, F.-W. (2006). Russland, Europa und die Welt-Perspektiven der Zusammenarbeit in globalen Sicherheitsfragen. 42. Münchner Konferenz für Sicherheitspolitik. Preuzeto 13. 9. 2017. s: Auswärtiges Amt, https://www.auswaertiges-amt.de/de/ newsroom/060205-muenchenkonferenz/219564

Szulecki, K. (2018). The Multiple Faces of Energy Security: An Introduction. U: Szulecki, K. (ur.). Energy Security in Europe. Divergent Perceptions and Policy Challenges. Palgrave Macmillan. Cham. str. 1-30.

Szulecki, K. i Westphal, K. (2018). Taking Security Seriously in EU Energy Governance: Crimean Shock and the Energy Union. U: Szulecki, K. (ur.) Energy Security in Europe. Divergent Perceptions and Policy Challenges. Palgrave Macmillan. Cham. str. 177-202.

Vijeće EU-a. (2004). Council Directive 2004/67/EC concerning measures to safeguard security of natural gas supply. Preuzeto 2. 5. 2017. s: EUR-Lex, https://eur-lex.europa.eu/legal-content/EN/TXT/?uri=celex:32004L0067

Vijeće EU-a. (2015). Council conclusions on Energy Diplomacy. 10995/15. Preuzeto 17. 9. 2018. s: Consilium Europa, https://www.consilium.europa.eu/en/press/press-releases/2015/07/20/fac-energy-diplomacy-conclusions/

Vlada RF-a (Правительство РФ). (2003). Энергетическая стратегия России на период до 2020 года. Preuzeto 21. 7. 2018. s: Российская газета, https:// rg.ru/2003/09/30/energeticheskajastrategija.html

Wallace, H. i Reh, C. (2015). An Institutional Anatomy and Five Policy Modes. U: Wallace, H., Polack, M. A. i Young, A. R. (ur.). Policy-Making in the European Union. Oxford University Press. Oxford, UK. str. 72-112.

Waltz, K. N. (2000). On Interdependence. Journal of International Affairs (Redefining Europe), 3 (1): 9-15. Preuzeto 7. 6. 2018. s: https:/www.saisjournal.eu/DOCUMENTS/VOLUMEPDFS/AEB8BBE7-D461-9DC8-2A1EC374A963F429.pdf 
Wunderlich, U. (2008). The EU -A Post-Westphalian Actor in a NeoWestphalian World? UACES 38th Annual Conference. Edinburgh, 1-3. rujna: UACES. Preuzeto 13. 12. 2018. s: https://www.uaces.org/documents/papers/0801/2008_JUWunderlich.pdf

Yergin, D. (2006). Ensuring Energy Security. Foreign Affairs, 85 (2): 69-82. DOI: $10.2307 / 20031912$.

\author{
Jelena Radić Đozić \\ A HIBRID EU RESPONSE TO RUSSIA'S \\ POLITICIZATION OF GAS TRADE AIMED AT \\ ENERGY SECURITY STRENGHTENING
}

\begin{abstract}
Summary
In the 21 st century the European Union is adapting to the politicization of its gas trade with the Russian Federation with a hybrid model: a mixture of different measures. In order to prevent, or at least to mitigate, Russian use of gas trade in a realistic power politics, the EU is responding with measures which are digressing from the economic perspective, especially free-market one, and getting closer to the political perspective. Non-market responses have become unavoidable primarily due to bringing the political element into a foreign trade relationship. Based on the analysis of the EU's responses to the threat, which has originated from the Russian politicization of gas trade, it is possible to follow the incremental transformation of the EU liberal-economic identity into an increasingly geopolitical one in a world that is becoming increasingly realistic, both in the energy field and in international affairs in general. The European Union has included concepts of solidarity and sovereignty in its energy policy, yet according to the EU High Representative for the Common Foreign and Security Policy, the EU has to "learn to use the language of power again".
\end{abstract}

Keywords: Russian Federation, European Union, Gas Trade, Politicization, Geopolitical Identity, Solidarity, Sovereignty

Jelena Radić Đozić zaposlenica je državne uprave i doktorica političkih znanosti.

Kontakt: Jelena Radić Đozić, Voćarska 1, 10437 Bestovje.

E-mail: jelenaradicdj@gmail.com 